\title{
KARSINOMA KANDUNG KEMIH
}

\author{
Samuel S. Senduk \\ LindaW. A. Rotty
}

\begin{abstract}
Bagian Ilmu Penyakit Dalam Fakultas Kedokteran Universitas Sam Ratulangi Manado Email: semmi_senduk@yahoo.com
\end{abstract}

\begin{abstract}
We reported a case of bladder carcinoma in a male of 65 years. The main complaints were hematuria, urinary frequency, dysuria, urgency, loss of weight, and pain in the genital area spreading to the lower abdomen. Diagnosis made by clinical, laboratory, and cytological examinations had no result. Final diagnosis was made by ultrasonography and cystoscopy, associated with transurethral biopsy and histopathological examination. The result was papillary transitional cell carcinoma, class II; and according to TNM it was a superficial bladder carcinoma in stadium at least T1. Transurethral resection of the tumor was done, and intravesical medicine was given (mitomycin C $40 \mathrm{mg}$ once a week for 6 weeks). The patient was advised to stop smoking and drinking coffee. The prognosis was good.
\end{abstract}

Keywords: hematuria, bladder tumor, USG, cystoscopy, tansurethral resection

\begin{abstract}
Abstrak: Telah dilaporkan kasus karsinoma kandung kemih pada seorang laki-laki berusia 66 tahun. Keluhan utama: hematuri, urgensi, disuri, frekuensi, penurunan berat badan, dan nyeri di kemaluan sampai perut bagian bawah. Diagnosis yang ditegakkan berdasarkan pemeriksaan klinis, laboratorium, sitologi tidak memberi hasil positif. Diagnosis pasti ditegakkan berdasarkan ultrasonografi dan sistoskopi, disertai biopsi transuretral dan pemeriksaan histopatologi. Hasil yang diperoleh karsinoma sel transisional papiler kelas II, dan berdasarkan TNM sebagai karsinoma kandung kemih superfisial dengan stadium sekurang-kurangnya T1. Penanganan yang dilakukan adalah reseksi tumor transuretral yang diikuti pemberian obat intravesika (mitomicyn C $40 \mathrm{mg}$ sekali seminggu selama 6 minggu), dan penderita dianjurkan untuk berhenti merokok dan berhenti minum kopi. Prognosis penderita ini baik.
\end{abstract}

Kata kunci: hematuria, tumor kandung kemih, USG, sistoskopi, reseksi transuretral

Karsinoma kandung kemih adalah suatu penyakit keganasan yang mengenai kandung kemih dan menempati urutan ke empat keganasan pada laki-laki, dan urutan ke 10 pada perempuan. ${ }^{1}$ Kejadian penyakit ini lebih tinggi pada orang kulit putih dibanding kulit hitam, 2,5 kali lebih sering pada laki-laki dibandingkan perempuan, dan terbanyak dijumpai pada usia 60-70 tahun. ${ }^{2,3}$

Etiologi penyakit ini diduga berhubungan dengan beberapa faktor, seperti: kebiasaan merokok, pekerjaan yang berkontak dengan zat kimia yang bersifat karsinogenik (golongan aromatik amin), obatobatan antara lain siklofosfamid, dan infeksi parasit schistosoma haematobium., ${ }^{2,4-6}$
Trauma fisik terhadap lapisan uroepitelial yang diinduksi infeksi, instrumensasi, dan kalkulus dapat meningkatkan resiko terjadinya keganasan. ${ }^{2}$ Terdapat beberapa zat yang diduga berhubungan dengan penyakit ini, tetapi belum dapat dibuktikan, seperti: kopi, alkohol, pemanis siklamat dan sakarin. 7,8

Secara histopatologi karsinoma kandung kemih terdiri dari $95 \%$ karsinoma sel transisional, 3\% karsinoma sel skuamosa, dan $2 \%$ adenokarsinoma. ${ }^{1,9,10}$ Tujuh puluh lima sampai delapan puluh persen tumor menyebabkan lesi superfisial, $20 \%$ terdapat invasi tumor ke otot, dan $5 \%$ telah bermetastasis. ${ }^{1,2,9}$ 
Gejala klinis karsinoma kandung kemih $80-90 \%$ berupa hematuria dan $25 \%$ mengeluh urgensi, frekuensi, disuri, dan nyeri pinggul setelah kencing. ${ }^{1,3,11}$ Lima persen dari penderita yang telah terjadi metastasis mengeluhkan penurunan berat badan, demam, nyeri tulang, dan gejala yang berhubungan dengan metastase di paru dan hati. ${ }^{4,5}$

Diagnosis karsinoma kandung kemih berdasarkan gejala klinis, pemeriksaan laboratorium, radiologi, ultrasonografi, dan tomografi komputer. ${ }^{3,5}$ Dengan biopsi jaringan dan pemeriksaan histopatologi dapat dipastikan diagnosis penyakit ini. ${ }^{5}$ Pengobatan dan prognosis penderita karsinoma kandung kemih tergantung pada stadium penyakit yang didasarkan pada pemeriksaan histopatologi. ${ }^{1,2}$

\section{LAPORAN KASUS}

Seorang laki-laki berusia 66 tahun, suku Minahasa, pekerjaan petani, dirawat di Rumah Sakit Umum Prof. Dr. R.D. Kandou Manado pada tanggal 2 April 2007 dengan keluhan utama buang air kecil bercampur darah.

Buang air kecil bercampur darah yang dialami sejak satu hari sebelum masuk rumah sakit disertai rasa nyeri pada perut bagian bawah. Rasa nyeri hilang setelah keluar gumpalan darah dari saluran kencing. Kencing bercampur darah sudah dialami sejak tiga bulan lalu sebelum masuk rumah sakit, sedikit-sedikit, pada awalnya hilang-timbul, dan tanpa rasa nyeri. Penderita sudah beberapa kali berobat ke poliklinik penyakit dalam dan diberikan obat antibiotika dan penghilang rasa nyeri. Lama-kelamaan kencing bercampur darah semakin sering dan disertai rasa nyeri yaitu di daerah kemaluan sampai perut bagian bawah. Riwayat demam, batuk, mual, muntah, nyeri tulang, dan kencing batu disangkal penderita.

Penderita juga mengeluh nafsu makan berkurang, dan berat badan turun dalam tiga bulan terakhir kurang lebih 5 kilogram. Tidak terdapat gangguan buang air besar. Riwayat tekanan darah tinggi sejak tiga bulan lalu, dan penderita datang kontrol dipoliklinik hipertensi dan diberiakan obat lisinopril $5 \mathrm{mg}$ sekali sehari. Riwayat kencing manis juga disangkal. Penderita mempunyai kebiasaan merokok selama 20 tahun terakhir sebanyak satu sampai dua bungkus sehari, peminum kopi, serta tidak mempunyai riwayat penggunaan obat sitostatika.

Pada pemeriksaan fisik didapatkan keadaan umum sedang dan kesadaran kompos mentis. Tekanan darah 140/80 $\mathrm{mmHg}$, frekuensi nadi $88 \mathrm{x} /$ menit, respirasi $24 \mathrm{x} /$ menit, suhu badan $36,5^{\circ} \mathrm{C}$, dan berat badan 54 kilogram. Konjungtiva anemis, sklera tidak ikterus, tekanan vena jugularis normal, tidak terdapat pembesaran kelenjar getah bening di servikal, aksila, serta supra dan infraklavikula. Pemeriksaan dada tidak tampak kelainan, fremitus raba paru kanan dan kiri sama, perkusi sonor pada kedua paru, suara napas vesikuler tanpa suara tambahan. Tidak terdapat pembesaran jantung, suara jantung satu dan dua normal, tidak ditemukan bising. Pada pemeriksaan perut didapatkan perut lemas, tidak ditemukan massa, rasa nyeri perut bagian bawah, pada penekanan hepar dan lien tidak teraba, ballotement kedua ginjal positif, dan bising usus normal. Anggota gerak dalam batas normal, dan tidak ditemukan pembesaran kelenjar getah bening dan edema tungkai. Pada pemeriksaan colok dubur didapatkan sfingter ani cekat, mukosa licin, tidak teraba massa, serta feses berwarna kuning.

Pada pemeriksaan laboratorium didapatkan hemoglobin 10,8 g/dl, leukosit $10.200 / \mathrm{mm}^{3}$, trombosit 220.000 , dengan hitung jenis: eosinofil $1 \%$, basofil $0 \%$, netrofil batang $3 \%$, netrofil segmen $66 \%$, limfosit $22 \%$, monosit $4 \%$, dan laju endap darah 35/54 mm. Gambaran darah tepi menunjukkan anemia normositik normokromik dengan morfologi normal. Gula darah sewaktu $96 \mathrm{mg} / \mathrm{dl}$, ureum $17 \mathrm{mg} \%$, kreatinin 1,0 mg\%, SGOT $21 \mathrm{u} / \mathrm{l}$, SGPT 19 $\mathrm{u} / \mathrm{l}$, alkali fosfatase 125, natrium 140,6, kalium 4,1, kalsium 8,8. Urinalisis berat jenis 1,010, $\mathrm{Ph} 6,5$, protein -, reduksi -, eritrosit +++, leukosit ++, nitrit -, keton -, 
urobilin normal. Sedimen urin leukosit 1120/LPB, epitel+, eritrosit padat dan berbentuk homogen. Waktu pendarahan 1' dan waktu pembekuan 8'15". Sitologi urin mengesankan sediaan hapus yang terdiri dari sel-sel eritrosit dan beberapa sel epitel, dengan kesimpulan tidak tampak sel-sel ganas. Pemeriksaan radiologi foto polos abdomen tidak tampak batu radioopak pada daerah traktus urinarius. Pemeriksaan foto dada didapatkan paru-paru dalam batas normal dan pada jantung terdapat elongasi aorta. Hasil rekam jantung dalam batas normal. Pemeriksaan ultrasonografi (USG) abdomen didapatkan hati dan kandung empedu normal, pada kedua ginjal tidak tampak batu, sistem pelviokalises melebar, batas kortiko-parenkimal menipis, dan pada vesika urinaria tampak gambaran polip. Kelenjar getah bening normal. Kesan polip vesika urinaria dengan kecurigaan suatu keganasan.

Berdasarkan gejala klinik, pemeriksaan fisik, laboratorium, radiologi, dan ultrasonografi penderita didiagnosis sebagai hematuri karena polip vesika urinaria, infeksi saluran kencing, hipertensi grade I, dan anemia karena hematuri. Penderita diberi pengobatan per oral siprofloksasin $500 \mathrm{mg}$ dua kali sehari, tramadol tiga kali sehari bila perlu, lisinopril $5 \mathrm{mg}$ sekali sehari, disertai pemasangan kateter urin. Anjuran untuk pemeriksaan kultur urin dengan tes sensitifitas dan dikonsulkan ke Bagian Bedah Urologi.

Perkembangan penderita pada hari ke lima: hasil pembiakan urin ditemukan kuman stafilokokus albus, dengan hasil uji sensitifitas kuman tersebut sensitif dengan obat amikasin, amoksisilin, fosfomisin, linesolid dan trimitrhoprim. Antibiotik diganti dengan amoksisilin dan asam klavulanat per oral tiga kali sehari, kemudian dikonsulkan ke Bagian Bedah Urologi dengan diagnosis kerja hematuri akibat polip vesika urinaria, curiga keganasan dengan infeksi saluran kencing, dan direncanakan untuk dilakukan sistoskopi. Pada hari ke enam penderita direncanakan pindah ke ruangan Bedah untuk persiapan sistoskopi, namun penderita menolak untuk pemerik- saan tersebut dan minta pulang. Penderita dianjurkan kontrol ke poliklinik bedah urologi dan poliklinik hipertensi.

Evaluasi selanjutnya satu bulan kemudian tanggal 28 Mei 2007, penderita kembali masuk RSU Prof. Dr. R.D. Kandou Manado dengan keluhan masih buang air kecil bercampur darah disertai nyeri perut bagian bawah. Penderita bersedia dilakukan sistoskopi dan trans-urethral resection. Pada sistoskopi ditemukan tampak gambaran trabekulasi dan massa pada kandung kemih dengan bentuk polipoid, tetapi tidak ditemukan batu. Dilakukan eksisi tumor dan selanjutnya dilakukan pembilasan kandung kemih. Keadaan otot-otot baik. Oleh karena terjadi perdarahan maka dilakukan kauterisasi serta dipasang kateter urin. Hasil histopatologi sediaan biopsi mengesankan suatu karsinoma sel transisional papiler kelas II. Berdasarkan sistoskopi dan hasil pemeriksaan histopatologi, penderita ini didiagnosis sebagai karsinoma sel transisional papiler kelas II, dan dianjurkan untuk pemberian obat intravesika mitomicin C $40 \mathrm{mg}$ setiap minggu selama 6 minggu.

\section{PEMBAHASAN}

Terdapat banyak faktor penyebab yang dihubungkan dengan terjadinya karsinoma kandung kemih, yaitu terutama karena merokok sigaret yang memberikan kontribusi sampai dengan $40-50 \%$, baik pada laki-laki maupun perempuan. ${ }^{1,2,12}$ Asap rokok mengandung 2 (alfa dan beta) naftilamin dan 4 aminobifenil. ${ }^{2}$ Empat zat aromatic amin yang bersifat karsinogenik dan telah terbukti menyebabkan karsinoma kandung kemih adalah: 2-naftilamin, benzidin, 3,3 diklorobenzidin, dan 4 aminobifenil di mana zat-zat tersebut banyak digunakan pada industri pencelupan, dan khususnya benzidin digunakan sebagai reagen pada laboratorium. ${ }^{6,12}$ Faktor lainnya adalah aniline dyes, radiasi eks-ternal, obatobatan phenacetin dan chlor-naphazine, penggunaan yang lama siklo-fosfamid sebagai imunosupresan, infeksi kronis dari schistosoma haematobium yang banyak terjadi di Mesir dan Tanzania, kopi, dan 
pemanis buatan seperti siklamat serta sakarin. ${ }^{1,2,4,6,12}$ Diduga kopi berhubungan erat dengan karsinoma kandung kemih, namun belum terbukti. ${ }^{7,8}$ Sakarin telah terbukti menyebabkan karsinoma kandung kemih pada tikus percobaan, namun belum terbukti pada manusia. ${ }^{6}$ Usia yang sering terkena antara 60-70 tahun, dan laki-laki dibandingkan perempuan adalah $2,5: 1$. $^{1-3}$ Kasus ini seorang laki-laki berusia 66 tahun dengan riwayat perokok dan peminum kopi.

Karsinoma dapat terjadi di pelvis ginjal, ureter, kandung kemih, dan uretra, namun $90 \%$ karsinoma ditemukan di kandung kemih, $8 \%$ di pelvis ginjal, dan $2 \%$ terjadi di ureter dan uretra. ${ }^{1}$ Karsinoma kandung kemih $95 \%$ adalah janis karsinoma sel transisional, $3 \%$ karsinoma sel skuamosa, 2\% adenokarsinoma, dan $<1 \%$ tumor sel kecil (dengan sindrom paraneoplastik). ${ }^{1,6}$ Karsinoma sel skuamosa sering berhubungan dengan iritasi kronik oleh benda asing seperti batu, pemasangan kateter, dan invasi schistosoma haematobium, sedangkan adenokarsinoma sering terjadi di puncak kubah dari kandung kemih. ${ }^{1,12,13}$ Pada penderita ini dilakukan pemeriksaan patologi anatomi dan didiagnosis sebagai karsinoma sel transisional papiler kelas II di kandung kemih.

Keluhan utama yang paling sering adalah hematuri, yaitu sebanyak $80-90 \%$ kasus. Disuri, frekuensi, dan urgensi ditemukan sebanyak 25\% kasus., ${ }^{2,3}$ Pada sekitar $5 \%$ kasus terdapat penurunan berat badan, demam, nyeri tulang, serta tanda dan keluhan yang berhubungan dengan metastasis ke hati dan paru-paru. ${ }^{5}$ Tanda klasik dari karsinoma kandung kemih adalah makroskopik hematuri tanpa rasa nyeri. $^{2,13}$ Awalnya mikroskopik dan makroskopik hematuri sering timbul dan hilang dengan sendirinya pada saat kencing, tanpa disertai nyeri baik pada saat bergerak atau istirahat. ${ }^{2,14}$ Karsinoma kandung kemih merupakan penyebab utama terjadinya makroskopik hematuri (40\% kasus). ${ }^{1,2}$ Keluhan disuri, frekuensi, dan urgensi menunjukkan telah terjadi invasi tumor pada otot detrusor kandung kemih. ${ }^{5,10}$ Pada kasus ini keluhan hematuri telah dialami sejak tiga bulan sebelum masuk rumah sakit, bersifat progresif dan disertai disuri, frekuensi, penurunan berat badan, dan nyeri di kemaluan sampai ke perut bagian bawah.

Karsinoma kandung kemih menyebar secara limfogen dan hematogen. Metastasis jauh sering ke tulang, hati, dan paru-paru. Anemia dapat terjadi bila metastasis ke sumsum tulang atau kehilangan darah yang kronis. Edema pada kedua tungkai disebabkan karena obstruksi pembuluh vena atau saluran limf. ${ }^{2,3}$ Bekuan darah dapat menyebabkan obstruksi uretra dengan akibat terjadi pembesaran dan nyeri pada kandung kemih dan pinggang; dapat terjadi hidroureter, hidronefrosis, dan pielonefritis. ${ }^{13}$ Pada pemeriksaan fisik kasus ini ditemukan konjungtiva anemis, nyeri tekan pada perut bagian bawah, ballottement kedua ginjal positif, tanpa terabanya hepar dan pembesaran kelenjar limf regional.

Pemeriksaan laboratorium yang rutin dilakukan adalah pemeriksaan darah lengkap, faal hati, faal ginjal, serta urinalisis lengkap. ${ }^{3}$ Untuk evaluasi dari hematuri yang dicurigai akibat adanya tumor kandung kemih perlu dilakukan pemeriksaan sitologi urin dan sistoskopi. ${ }^{1}$ Hasil sitologi urin yang positif mengindikasikan adanya karsinoma sel transisional, tetapi tanpa adanya gejala klinis yang mendukung maka hasil sitologi urin tersebut tidak cukup berarti, karena sering ditemukannya hasil positif palsu. ${ }^{15}$ Dugaan karsinoma sel transisional kandung kemih berdasarkan sitologi urin harus dikonfirmasi dengan sistoskopi dan biopsi transuretral. ${ }^{1,10}$ Pada penderita ini ditemukan anemia normositik normokromik. Terdapat hematuri makroskopik dan sitologi urin yang mengesankan hanya terdiri dari sel-sel eritrosit dan beberapa sel epitel, dan tidak tampak sel-sel ganas. Hasil biopsi transuretral menunjukkan gambaran histopatologik sesuai dengan karsinoma sel transisional papiler kelas II (Gambar 1).

Pemeriksaan lain yang dianjurkan adalah foto toraks, pielografi intravena, serta tomografi komputer abdomen. Foto toraks dapat mendeteksi adanya metastasis tumor ke paru-paru. ${ }^{2,5}$ Pielografi intravena digunakan untuk menentukan adanya obs- 
truksi pada ureter, pelebaran lokal, dan tumor pada sistem pelvio-kalises atau ureter. ${ }^{5}$ Bila tampak adanya filling defects yang radiolusen di kandung kemih pada pemeriksaan pielografi intravena dan tomografi komputer abdomen, maka harus dicurigai adanya karsinoma kandung kemih. $^{2,5}$

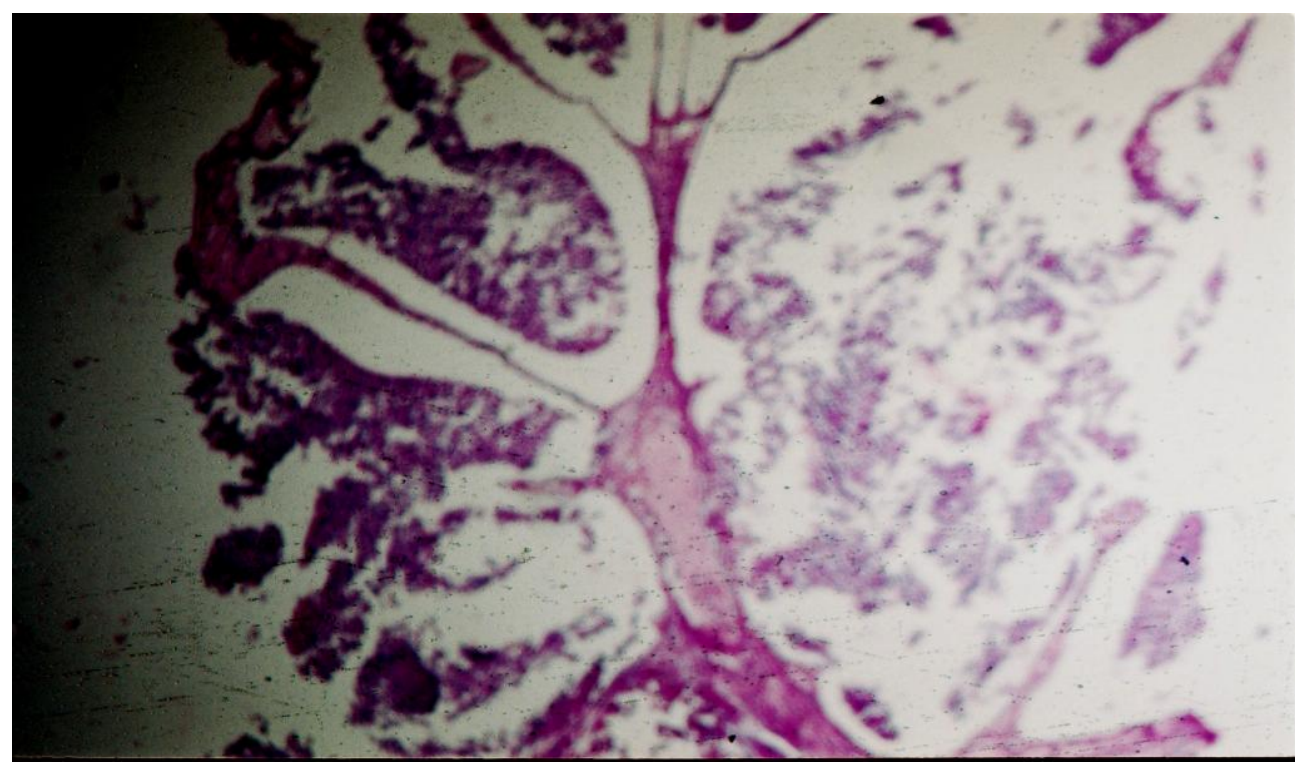

Gambar 1. Gambaran histopatologi dari karsinoma transisional papiler kelas II.

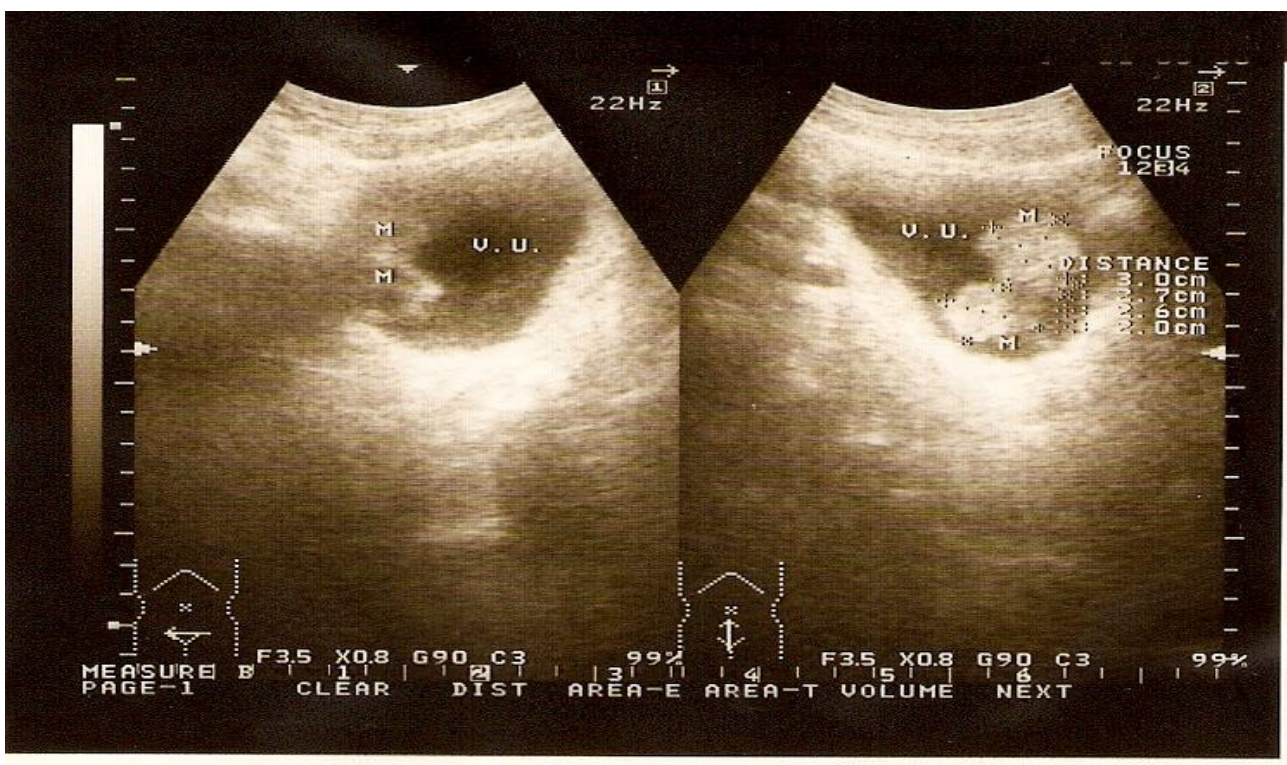

Gambar 2. Gambaran Ultrasonografi yang menunjukkan suatu polip kandung kemih

Tomografi komputer abdomen dapat mendeteksi adanya pembesaran kelenjar limf di pelvis dan abdomen, tetapi hanya sensitif jika ada invasi lokal tumor. ${ }^{2,5,6}$ Alat tersebut berkemampuan terbatas (40-85\%) untuk membedakan adanya invasi tumor yang dalam (T2) dengan invasi peri-vesika (T3). ${ }^{1,2,4}$
Tomografi komputer abdomen dan scan tulang dilakukan pada penderita yang mengeluh nyeri tulang, peningkatan serum alkali fosfatase, atau peningkatan serum transaminase. ${ }^{3}$ Ultrasonografi direkomendasikan penggunaannya karena berkemampuan untuk mendeteksi tumor yang lebih besar dari $1,5 \mathrm{~cm}$ pada $58-94 \%$ kasus, teta- 
pi tidak dapat digunakan untuk menentukan derajat tumor. Ultrasonografi transurethral dapat mempertinggi keakuratan diagnosis. ${ }^{5}$ Sistoskopi dan biopsi pada dae-rah yang abnormal merupakan kunci diag-nosis dan gradasi dari karsinoma kandung kemih. ${ }^{2,3}$ Pada penderita ini foto toraks tidak memperlihatkan metastasis tumor. Pemeriksaan ultra-sonografi transabdominal mengesankan terdapatnya polip kandung kemih, yang dikonfirmasi oleh adanya karsinoma sel transisional dengan sistoskopi dan biopsi jaringan tumor.

Pengangkatan seluruh tumor penting untuk menegakkan diagnosis, sebagai tindakan terapi, dan untuk menentukan adanya invasi tumor yang menembus lapisan otot. ${ }^{1}$ Tujuh puluh lima persen karsinoma sel transisional terdapat dalam bentuk lesi superfisial, $20 \%$ terdapat invasi ke otot, dan 5\% terdapat metastasis tumor. ${ }^{1}$ Dengan berdasarkan pada diferensiasi histologiknya maka karsinoma kandung kemih dibedakan atas tiga kelas: kelas I tumor berdiferensiasi baik, kelas II tumor berdiferensiasi sedang, dan kelas III tumor berdiferensiasi buruk. ${ }^{5}$ Tumor yang berdiferensiasi baik jarang berkembang menjadi stadium yang lebih tinggi, sedangkan tumor yang berdiferensiasi buruk mempunyai resiko tinggi berkembang menjadi stadium yang lebih buruk. ${ }^{1}$ Pada kasus ini didapatkan hasil biopsi karsinoma sel transisional papiler dengan diferensiasi sedang (kelas II).

Penentuan stadium dibutuhkan untuk menentukan perluasan penyakit secara anatomi. Sistem yang umum dipakai adalah TNM (Tumor-NodeMetastasis) staging system., ${ }^{2,5}$ Untuk menentukan stadium tumor perlu dilakukan pemeriksaan seperti sistoskopi, pielografi intravena, komputer tomografi pelvis/abdomen, magnetic resonance imaging (dengan akurasi 85-94\%), ultrasonografi, scan tulang, foto toraks, dan pemeriksaan laboratorium (darah lengkap, ureum, kreatinin, kalsium, dan alkali fosfatase). ${ }^{3}$ Berdasarkan TNM yaitu: TIS adalah tumor in situ, Ta adalah tumor papilari non invasif, $\mathrm{T} 1$ adalah tumor pada jaringan ikat subepitel, T2 adalah tumor pada otot superfisial, T3 tumor mengenai otot bagian dalam (T3A) atau jaringan lunak perivesika (T3B), T4 tumor mengenai prostate, uterus, vagina, dinding pelvis, dan dinding abdomen. NO tidak terdapat metastasis kelenjar regional, N1 terdapat metastasis kelenjar regional (tunggal) dengan diameter $\leq 2 \mathrm{~cm}, \mathrm{~N} 2$ terdapat metastasis kelenjar regional tunggal $>2 \mathrm{~cm}$ dan $<5 \mathrm{~cm}, \mathrm{~N} 3$ terdapat metastasis kelenjar regional multipel > 5 $\mathrm{cm}$. M0 artinya tidak terdapat metastasis, sedangkan M1 terdapat metastasis jauh ${ }^{3}$. Berdasarkan TNM staging system, penderita ini diperlakukan sebagai karsinoma kandung kemih yang superfisial, sekurang-kurangnya stadium T1 (Tabel 1).

Penatalaksanaan karsinoma kandung kemih dilakukan berdasarkan sistem TNM. Pada karsinoma kandung kemih yang superfisial (TIS, Ta, T1) biasanya dilakukan reseksi tumor transuretral dan diikuti pemberian obat kemoterapi atau imunoterapi intravesika. ${ }^{1-3,11}$ Pemberian obat intravesika yang banyak digunakan adalah mitomycin C (MMC), doxorubicin, dan Bacillus Calmette-Guerin (BCG). ${ }^{1,2,16}$ Pemberian BCG intravesika bersifat imunoterapi dengan menekan rekurensi serta progresifitas dari karsinoma kandung kemih sehingga diindikasikan untuk penderita-penderita yang cenderung mengalami kekambuhan setelah operasi reseksi transuretral. ${ }^{1,12,16}$

BCG mengurangi kekambuhan $40 \%$ $45 \%$, dibanding obat intravesika lain yang hanya sebesar $8-18 \%{ }^{2,16}$ Pada beberapa penelitian penggunaan MMC dosis minimal sebagai kemoterapi intravesika telah menunjukkan efektifitas yang sangat tinggi terhadap karsinoma kandung kemih. Selain itu tidak mengakibatkan efek samping yang serius. ${ }^{16-18}$

MMC paling efektif diberikan sesegera mungkin setelah operasi, dimana MMC akan melapisi lapisan mukosa kandung kemih dan bekerja menghentikan pertumbuhan menghentikan pertumbuhan 
Tabel 1. Perbandingan TNM dan Jewett-Strong-Marshall Staging Systems. ${ }^{2,5}$

\begin{tabular}{|c|c|c|}
\hline \multicolumn{3}{|c|}{ Comparison of the TNM and Jewett-Strong-Marshall Staging Systems } \\
\hline TNM* Stage & JSMt Stage & Definition \\
\hline TTS & 0 & Carcinoma in situ, confined to the mucosa \\
\hline $\mathrm{Ta}$ & & Tumor confined to the mucosa \\
\hline T1 & A & Infiltration of the lamina propria \\
\hline $\mathrm{T} 2 \mathrm{~A}$ & $\mathrm{~B}_{1}$ & Extension to the superficial muscular layer \\
\hline $\mathrm{T} 2 \mathrm{~B}$ & B2 & Extension to the deep muscular layer \\
\hline $\mathrm{T} 3 \mathrm{~A}$ & $\mathrm{C}$ & Infiltration of perivesical fat (microscopic) \\
\hline $\mathrm{T} 3 \mathrm{~B}$ & & Infiltration of perivesical fat (macroscopic) \\
\hline T4A & D1 & Invasion of the prostate, uterus, or vagina \\
\hline T4B & & Invasion of the pelvic or abdominal wall \\
\hline No & & No lymph node metastasis \\
\hline N1 & & Metastasis to a single lymph node $\leq 2 \mathrm{~cm}$ in greatest dimension \\
\hline $\mathrm{N} 2$ & & $\begin{array}{l}\text { Metastasis to a single lymph node }>2 \mathrm{~cm} \text { but } \leq 5 \mathrm{~cm} \text { in great- } \\
\text { est dimension or to multiple lymph nodes }\end{array}$ \\
\hline N3 & & Metastasis to a lymph node $>5 \mathrm{~cm}$ in greatest dimension \\
\hline Mo & & No distant metastasis \\
\hline Ml & $\mathrm{D} 2$ & Distant metastasis \\
\hline
\end{tabular}

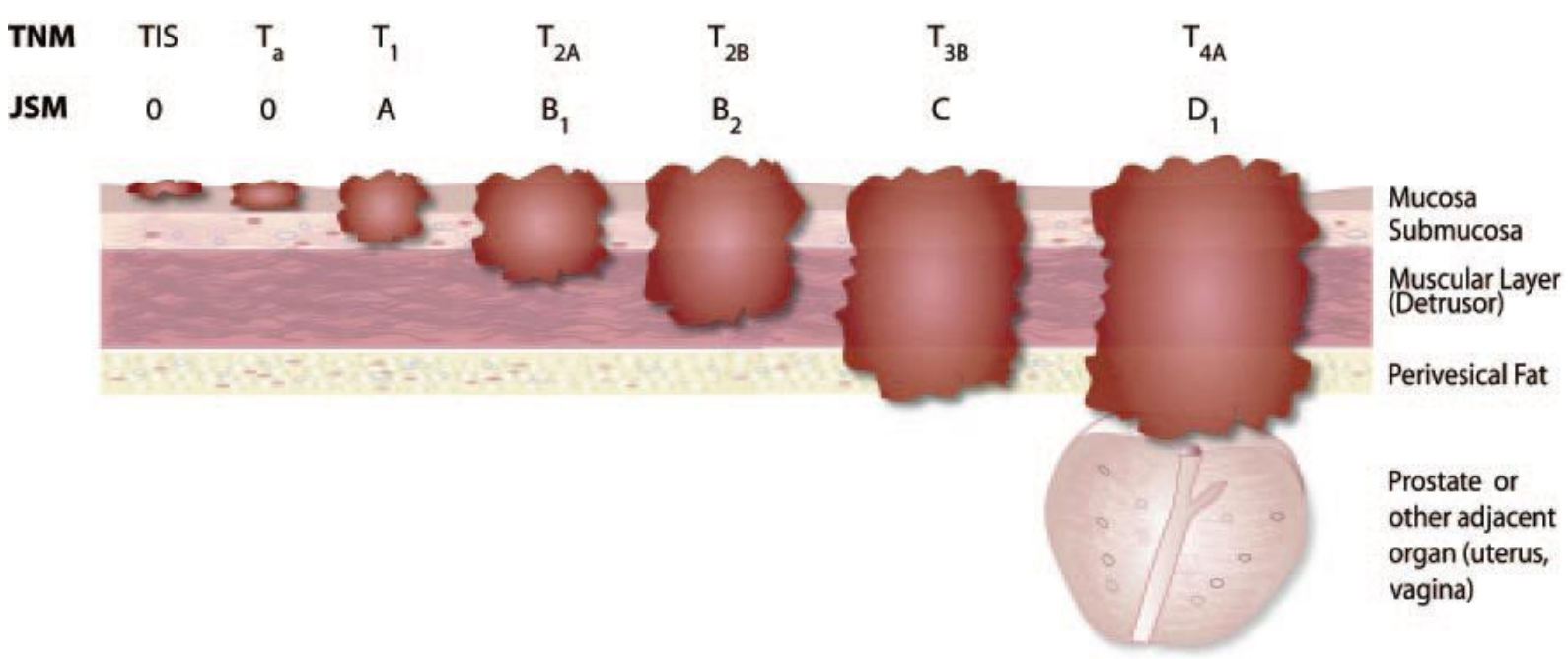

Correlation of the extent of tumor invasion with the TNM staging system of the International Union against Cancer and the Jewett-Strong-Marshall (JSM) staging system. The muscular layer is missing in bladder diverticula. The reflection of peritoneum that makes up the serosal layer of the upper bladder is not shown.

serta pembelahan sel-sel kanker tersebut. ${ }^{19}$ Tujuan dari terapi ini adalah untuk mematikan sel-sel kanker sehingga mukosa kandung kemih akan terbebas dari sel-sel kanker, yang dengan demikian akan mengurangi angka kekambuhan sampai dengan 40\%. ${ }^{19}$ Standar terapi untuk karsinoma kandung kemih yang invasif sampai ke otot (T2, T3) adalah sistektomi radikal yang di beberapa negara telah digunakan sebagai terapi standar utama. ${ }^{1,2,5}$ Radioterapi sebesar 5000-7000 cGy selama periode pemberian 5-8 minggu berperan sebagai pengobatan alternatif dengan angka harapan hidup lima tahun sebesar 3045\%. ${ }^{1,2}$ Karsinoma kandung kemih metastasis (T4) yang menggunakan obat kemoterapi, biasanya berupa kombinasi M-VAC (Methotrexate, Vinblastin, Adriamycin, dan Cisplatin), PT (Ciplastin dan Paklitaksel), GTC (Gemsitabin, Paklitaksel, Ciplastin), atau CISCA (Cisplatin, Siklofosfamid, Adriamycin). ${ }^{1-3}$ 
Penderita ini diperlakukan sebagai karsinoma kandung kemih yang superfisial sekurang-kurangnya stadium $\mathrm{T} 1$, sehingga penanganan yang dilakukan adalah reseksi tumor transurethral, dan diikuti pemberian obat intravesika (mitomycin C $40 \mathrm{mg}$ sekali seminggu selama 6 minggu). Juga penderita dianjurkan untuk berhenti merokok dan minum kopi.

Prognosis penderita karsinoma kandung kemih tergantung dari pada kelas histologi dan stadium penyakit. ${ }^{5}$ Karsinoma yang telah menginvasi jaringan perivesika dan bermetastasis ke jaringan limf mempunyai prognosis yang buruk. ${ }^{2}$ Angka harapan hidup lima tahun untuk karsinoma yang invasif adalah $45-55 \% .{ }^{20}$ Karsinoma kandung kemih kelas I yang soliter mempunyai angka kekambuhan 30-35\%, sedangkan untuk tumor multipel $65-75 \%{ }^{20}$ Pada karsinoma kandung kemih yang telah dilakukan sistektomi maka penderita dengan tumor yang berdiferensiasi baik mempunyai angka harapan hidup lima tahun sebesar 70$80 \%$, sedangkan yang berdiferensiasi buruk sebesar $35-40 \%$. $^{4}$ Prognosis penderita ini baik oleh karena pada saat ditemukan masih pada stadium yang superfisial dan non invasif (Ta), sehingga hanya dilakukan reseksi tumor transuretral yang kemudian diikuti pemberian obat kemoterapi intravesika.

\section{KESIMPULAN}

Telah dilaporkan kasus karsinoma kandung kemih pada seorang laki-laki berusia 66 tahun. Diagnosis ditegakkan berdasarkan pemeriksaan klinis, laboratorium, ultrasonografi, dan sistoskopi yang menunjukkan adanya tumor pada kandung kemih. Histopatologi dari biopsi jaringan menunjukkan gambaran suatu karsinoma sel transisional papiler kelas II. Berdasarkan TNM Staging System penderita ini diperlakukan sebagai karsinoma kandung kemih yang superfisial sekurang-kurangnya stadium T1.

\section{DAFTAR PUSTAKA}

1. Scher HI, Motzer RJ. Bladder and renal cell carcinomas. In: Kasper DL, Fauci AS, Braunwald E, et al (Eds). Harrison's Principles of Internal Medicine. $16^{\text {th }}$ ed, vol. 1. New York: Mc Graw Hill, 2005; p. 539-40.

2. Grossfeld GD, Carroll PR. Urothelial carcinoma: cancers of the bladder, ureter, \& renal pelvis. In: Tanagho EA, McAninch (Eds). Smith's General Urology. $16^{\text {th }}$ ed. New York: Mc Graw Hill, 2004; p. 324-45.

3. Casciato DA, Lowitz BB. Manual of clinical oncology. $4^{\text {th }}$ ed. Philadelphia: Lippincott Willians \& Wilkins, 2000; p. 284-91.

4. Murta-Nascimento C, Schmitz-Drager BJ, Zeegers MP, Steineck G, Kogevinas M, Real FX, et al. Epidemiology of urinary bladder cancer: from tumor development to patient's death. World J Urol. 2007; 25(3): 285295.

5. Rubin P, Mc Donald S, Qazi R. Clinical oncology a multidisciplinary approach for physicians and students. $7^{\text {th }}$ ed. Philadelphia: WB Saunders, 1993; p. 425-31.

6. Doll R, Peto R. Epidemiology of cancer. In : Weatherall DJ, Ledingham JGG, Warrell DA (Eds). Oxford Textbook of Medicine. $3^{\text {rd }}$ ed, vol. 1. Oxford: Oxford University Press, 1996; p. 197-237.

7. Viscoli CM, Lachs MS, Horwitz RI. Bladder cancer and coffee drinking: a summary of case control research. Lancet. 1993; 341: 1432-7.

8. Zeegers M, Volvolics A, Dorant E, et al. Alcohol consumption and bladder cancer risk: Result From The Netherlands Cohort Study. Am J Epidemiol. 2001;153:38-41.

9. Effert J, Seifert P. In invasive potential of noninvasive human bladder carcinoma: An Electron Microscopy Study. Am J Clin Pathol 2003; 120: 188-93.

10. Paulson DF. The urinary system. In: Sabiston DC, Lyerly HK (Eds). Textbook of Surgery The Biological Basic of Modern Surgical Practice. $15^{\text {th }}$ ed. Philadelphia: WB Saunders, 1997; p. 1524-51.

11. Pereira JH, Towler JM. Ten cases of transitional cell carcinoma of bladder 
causing ureteric obstruction. Br J Urol 1990; 66: 628-30.

12. Jancovic S, Radosavljevic. Risk factors for bladder cancer. Tumori. 2007; 93: 4-12.

13. Rozanski TA, Grossman HB. Recent developments in the pathophysiology of bladder cancer. Am J Rad. 1994; 163: 789-92.

14. Natale R. Tumors of the kidney, ureter, and bladder. In: Kelley WN, Devita VT, Dupont HL., et al (Eds). Textbook of Internal. $2^{\text {nd }}$ ed. Philadelphia: JB Lippincott, 1992; p. 749-51.

15. Schwalb DM, Herr HW, Fair WR. The management of clinically unconfirmed positive urinary cytology. J Urol 1993; 150: 1751-56.

16. Jeong C.W, Jeon H.G, Kwak C, et al. Comparison of $30 \mathrm{mg}$ and $40 \mathrm{mg}$ of mitomycin $\mathrm{C}$ intravesical instillation in Korean superficial bladder cancer patients: Prospective, Randomized Study. Cancer Research and Treatment. 2005; 37(1): 44-7.

17. Au Jessie L.S, Badalament R.A, Wientjes M.G, et al. Methods to improve efficacy of intravesical mitomycin C: Results of a randomized phase III trial. Journal of the National Cancer Institute. 2001; 93(8): 597-604.

18. Somerville J.J.F, Newling D.W.W, et al. Mitomycin $\mathrm{C}$ in superficial bladder cancer : 24-month Follow - Up. British Journal of Urology. 1985; 57: 686-89.

19. Sillwood N, Skelton B. Intravesical mitomycin chemotherapy. Royal Berkshire Hospital Switchboard. [homepage on the internet] Revised January 2008. www.cancerbackup.org.uk

20. Rosai J. Surgical pathology. $7^{\text {th }}$ ed. St Louis: Mosby Company, 1989; p. 90413. 